\title{
Numerical Analysis of Airborne Infection Control Performance of Germicidal Systems in a Temporary Shelter
}

\author{
수치해석을 이용한 임시대피소 내 공기감염확산 저감장치의 성능 분석
}

Park, Jeongyeon* 박정연 | Sung, Minki ${ }^{\star *}$ 성민기 | Lee, Jaewook** 이재욱

\begin{abstract}
Purpose: When natural disaster occurs, the victims are evacuated to temporary shelters such as indoor gymnasiums or large space buildings until their homes are recovered. If someone in this temporary shelter is infected with an airborne infectious disease, it becomes easier for the disease to spread to the other people in the shelter than it would be under normal conditions. Therefore, temporary shelters need to provide not only water and food but also hygienic indoor conditions. Methods: In this study, the use of mechanical systems such as ultraviolet germicidal irradiation (UVGI) systems and air cleaners were simulated using numerical analysis to find out how these systems can control airborne infection in temporary shelters. An indoor gymnasium was selected as a temporary shelter for the numerical simulation model considering Korea's post-disaster response system. Influenza A virus was assumed as an airborne infectious disease and the diffusion of the virus was made by one person in the shelter. Results: The result of this study showed that the UVGI systems disinfected the virus more effectively than the air cleaners by creating a more stable airflow after the disinfection process. The air cleaners could remove the virus but since it created an unstable airflow in the temporary shelter, the virus was condensed to a certain area to show a higher virus concentration level than the source location. Implications: In the temporary shelter, it is necessary to use UVGI systems or air cleaners for hygienic indoor conditions.
\end{abstract}

Keywords Temporary shelter, Numerical analysis, Airborne infection, UVGI system, Air cleaner. 주 제 어 임시대피소, 수치해석, 공기감염, UVGI 시스템, 공기청정기

\section{Introduction}

\subsection{Background and Objective}

갑작스런 폭우나 홍수로 인해 가옥의 침수와 같은 대규모 재난이 발생할 경우, 피해가 복구되기까지 이재민들은 임시대 피소에서 생활하게 된다. 실제로 2011년 국내에서는 수해로 인한 피해가 복구되기까지 이재민들이 학교 내 실내 체육관 과 같은 대공간을 임시대피소로 사용한 사례들이 있다. 실내 체육관이나 그 외 대공간 건물 등과 같은 시설들이 본래 계획

* Master candidate, Architectural Environment Engineering and Research Lab, Sejong University

** Professor, PhD, Department of Architectural Engineering, Sejong University (Corresponding author: mksung@ sejong.ac.kr)

*** Professor, PhD, Department of Architectural Engineering, Sejong University
한 용도와 다른 임시대피소로 사용될 때 이재민들에게 쾌적 하고 안전한 실내환경을 제공하는 것은 쉽지 않다. 또한 실내 환경을 위생적으로 유지하기 어렵기 때문에 임시대피소 내에 서 공기감염병이 확산될 위험도 높아진다고 할 수 있다. Hajime et al. (2013: 801)에 따르면, 2011년 일본의 대지진 당 시 임시대피소 내의 결핵 감염환자로 인해 다른 이재민들에 게 결핵이 전파된 사례를 확인할 수 있다. 또한 Wrezel (2009: 63)은 임시대피소와 유사한 시설인 노숙자 임시보호시설에서 재실자가 결핵, 폐렴, 인플루엔자와 같은 공기감염병에 쉽게 감염될 수 있는 것을 확인하였고, 각 공기감염병 별로 실제 감 염사례 및 감염확산 저감에 대해 간략하게 기술하고 있다.

이와 같이 임시대피소나 그와 유사한 노숙자 보호 수용시 설 등은 비교적 위생상태가 열악하며 쾌적한 실내환경을 유 지하기가 어렵기 때문에 국외에서는 이러한 시설에 있어서 
공기감염병의 확산을 저감하기 위한 다양한 연구가 진행되고 있다. 실내에 재실자가 많고 감염확산 저감에 취약한 노숙자 임시보호시설과 같은 시설에서의 공기감염병의 확산을 저감 하기 위해, Public Health Seattle-King County (2010)와 Curry International Tuberculosis Center (CITC, 2013)에서 시설의 운영 및 필요 장치에 대한 가이드라인을 제시하고 있다. Public Health Seattle-King County (2010: 21)에서는 공기감 염병인 결핵이 인구밀도가 높고 환기 및 실내 공기의 순환이 잘 되고 있지 않는 임시시설에서 확산될 수 있음을 확인하였 다. 또한 공기감염병의 확산 저감을 위해 자연환기나 기계식 환기의 사용과 실내 상부형 UVGI(자외선 살균)를 통한 방안 을 제시하고 있다. 다른 장치에 비해 비교적 가격이 저렴한 HEPA 필터를 사용하는 방안 또한 제시하고 있다. CITC (2013: 15)도 마찬가지로 공기감염병인 결핵 확산을 저감하는 방안 으로 환기와 실내 상부형 UVGI, HEPA 필터를 사용하는 것을 제시하고 있다. 그 외에 임시시설 내의 침대의 배열, 개인의 위생 관리와 같은 방안을 공기감염병의 확산을 저감하는 것 으로 제안하고 있다. First M.W. (1999)는 실내 상부에 설치하 여 부유균을 살균하는 장치인 실내 상부형 UVGI를 사용하여 공기감염병의 확산을 저감하는 방안에 대하여 언급하고 있으 며, Association for Professionals in Infection Control and Epidemiology (APIC, 2008)에서는 재난으로 인해 이재민들이 임시대피소 내에서 생활할 경우, 공기감염병의 감염확산을 저 감하기 위한 대안으로 기본적으로 지켜야 하는 위생, 음식, 식 수 등에 대한 관리방안을 제시하고 있다.

그러나 국내의 경우 임시대피소와 같은 시설 내에서 공기 감염균의 확산 저감을 위한 위생적인 실내환경에 대한 인식 이나 대응이 아직 부족한 상황이다. 따라서 본 연구에서는 공 기감염균의 확산 저감을 위한 대표적인 장치인 실내 상부형 UVGI 시스템과 공기청정기를 대상으로 수치해석을 수행하여 공기감염균의 확산을 저감하는 성능과 적용 가능성을 검토하 였다.

\subsection{Scope of Research}

본 연구의 선행 연구에서는 임시대피소로 가정한 초등학교 실내체육관을 대상으로 가스상 물질로 가정한 공기감염균의 확산을 예측하였다 (박정연 외, 2014). 또한 공기감염균 저감 장치 중 살균효과가 입증된 실내 상부형 UVGI와 공기청정기 의 공기감염균 확산 제어 성능을 수치해석을 통해 비교하였 다. 그 결과, 실내 상부형 UVGI와 공기청정기 모두 임시대피 소 내에서 공기감염균에 대한 저감 성능을 확인하였다.

본 연구는 기존 연구와 같이 감염확산을 확인하는 데에 그 치지 않고 공기감염균의 확산을 줄이며 공기감염균의 농도를 감소시킬 수 있는 방안에 대하여 추가 분석을 진행하였다. 선 행 연구에서 부족하였던 부분을 보완하여, 감염원의 위치에
따른 공기감염균의 확산에 대한 분석과 공기청정기의 감염확 산 저감 성능에 대하여 추가로 분석을 진행하였다. 공기감염 균을 가스상 물질로 가정하여 수치해석 프로그램을 이용해 임시대피소 내 공기감염균의 확산 및 저감장치의 감염확산 저감 성능을 분석하였다.

\section{Methods of Research}

\subsection{Temporary Shelter Model}

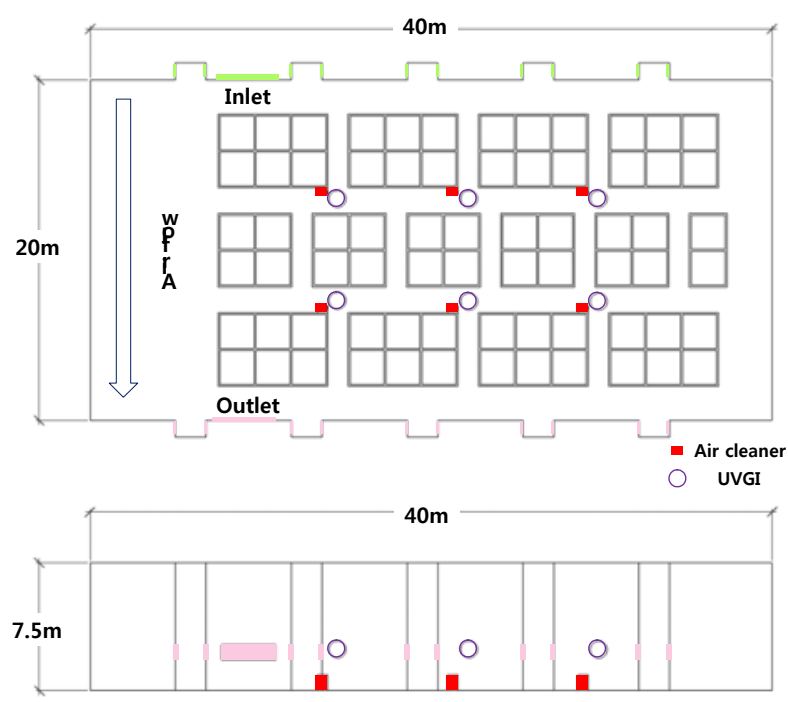

[Figure 1] Temporary Shelter Model

APIC(2008)에 의하면, 임시대피소란 안전과 음식, 옷과 기 본 응급 치료까지 그곳에 머무는 사람들에게 제공이 가능하 도록 설립된 대피소를 말한다. 주로 기숙사 또는 야영장 등이 나 교회, 학교 또는 체육관과 같은 대규모 건물이 임시대피소 로 활용될 수 있다. 따라서 본 연구에서는 임시대피소로 활용 가능한 서울 소재 모 초등학교 $(20 \mathrm{~m} \times 40 \mathrm{~m} \times 7.5 \mathrm{~m})$ 를 대상 모델로 가정하였다 (Figure 1). 대상 모델의 출입구를 기준으 로 좌측과 우측에 각각 $1 \mathrm{~m} \times 0.8 \mathrm{~m}$ 의 창 10 개와, $3.2 \mathrm{~m} \times$ $0.9 \mathrm{~m}$ 의 창이 1 개씩 총 22 개의 창이 있으며, 실제 시설과 유사 하게 별도의 냉난방 및 환기설비는 없는 것으로 가정하였다. 임시대피소 내 1인당 피난면적은 미국 Centers for Disease Control and prevention $(\mathrm{CDC})$ 의 기준에 따라 $2 \mathrm{~m}^{2}$ 으로 설정 하였다.

\subsection{Numerical Analysis Method}

임시대피소 내 감염확산을 확인하는 실험을 실제로 진행 하기에 한계가 있기 때문에 수치해석을 통해 공기감염균의 확산 및 장치의 감염확산 저감 성능을 비교 및 분석하였다. 또한 임시대피소 내 감염환자의 정확한 위치를 파악하는 것 이 어렵다. 그렇기 때문에 본 연구에서는 감염환자의 위치를 임시대피소의 중앙에 위치한 것으로 가정하였다. 공기감염균 
의 확산 저감을 위한 장치의 경우, 살균 효과가 입증된 실내 상부형 UVGI와 고효율의 HEPA 필터가 장착된 공기청정기를 대상으로 하였다. 감염확산 저감을 위한 방법으로 실내 상부 형 UVGI와 공기청정기와 같은 저감 장치 외에 피난민들의 프라이버시를 위해 사용되는 경우가 있는 칸막이 설치의 영 향도 함께 검토하였다. 칸막이를 설치하여 피난구역을 분리 하였을 경우, $2 \mathrm{~m} \times 2 \mathrm{~m} \times 2 \mathrm{~m}$ 칸막이를 사용하는 것으로 가정하였다.

본 연구에서 감염의 경로는 공기감염으로 정의하였다. 공 기감염이란 감염성 미생물을 포함한 $5 \mu \mathrm{m}$ 이하의 작은 입자 (비말핵, droplet nuclei)들이 공기 중에 떠다니다 호흡기를 통 해 감염병이 전파되는 것을 말한다 (OSHA, 2009: 11). 이러한 경로로 퍼지는 미생물의 경우, 기류를 타고 먼 거리까지 퍼질 수 있다. 공기감염을 일으키는 미생물은 주로 결핵균, 홍역 바 이러스, Influenza A 바이러스 등이 있다. 공기감염병 중 Influenza $A$ 를 대상으로 하여 임시대피소 내 감염확산과 감염 확산 저감 장치의 성능을 분석하였다. 공기감염균은 거동이 유사한 가스상 물질로 가정하고, 감염확산은 감염물질로 가정 한 가스상 오염물질의 농도 분포로 표현하였다.

먼저 임시대피소 내 재실자 1 명을 Influenza A 감염환자로 가정하고, Influenza A의 감염환자 (source) 는 그림 1 과 같이 실의 중앙에 위치하고 있다. 피난 구역은 총 70 개로 나누어져 있으며 피난 구역 당 2 명의 재실자가 있어 총 140 명이 재실하 고 있는 것으로 가정하였다. 피난 구역마다 외기의 온도는 간 절기 (10월) 서울의 평균온도인 $16{ }^{\circ} \mathrm{C}$, 임시대피소 내의 온도 는 $20^{\circ} \mathrm{C}$ 로 가정하였다. 대상 모델 좌측의 창 11 개를 급기구, 우측의 동일한 규격의 창을 배기구로 설정하고 환기횟수는 건축물의 설비 기준 등에 관한 규칙 (2013 개정 전) 에 의해 공동주택의 필요 환기횟수 0.7 회로 설정하고, 자연환기가 되 고 있는 상황을 가정하여 수치해석을 진행하였다. 또한 임시 대피소 내 재실자의 열부하와 벽체 및 출입문의 열 손실량을 계산하여 수치해석에 반영하여 계산을 진행하였다. 그 외의 수치해석 조건은 [Table 1]과 같다.

[Table 1] Numerical Analysis Conditions

\begin{tabular}{c|l}
\hline CFD code & Star-CCM+ v.9 \\
\hline $\begin{array}{c}\text { Analysis } \\
\text { Method }\end{array}$ & $\begin{array}{l}\text { Mesh: about } 500,000 \\
\text { Turbulence model: Standard k- } \varepsilon \text { model }\end{array}$ \\
\hline \multirow{3}{*}{ Boundary } & $\begin{array}{l}\text { Supply air: } 16{ }^{\circ} \mathrm{C}, 0.12 \mathrm{~m} / \mathrm{s}(4,649 \mathrm{CMH}) \\
\text { Exhaust air: } 0.12 \mathrm{~m} / \mathrm{s} \\
\text { Wall: Wall function } \\
\text { Heat source: Human }(96 \mathrm{~W} / \mathrm{man}) \\
\text { * Heat loss through the wall, roof }(3.04 \\
\left.\text { W/m } / \mathrm{m}^{2}\right) \text { and door }\left(80 \mathrm{~W} / \mathrm{m}^{2}\right)\end{array}$ \\
\hline
\end{tabular}

감염확산 수치해석의 Case는 [Figure 2]와 같다. 해석 Case 는 크게 임시대피소 내에 칸막이의 설치유무에 따라 나누었 다. Case 1 의 경우 자연환기만을 하는 case로, 본 연구에서의 control case이다. 실내 상부형 UVGI를 사용한 case의 경우, 인체에 영향을 주지 않도록 바닥으로부터 높이 $2.4 \mathrm{~m}$ 에 피난 구역의 주 통로에 실내 상부형 UVGI 6 대가 설치되어 있는 것 으로 가정하였다. 공기청정기를 사용한 case의 경우 기존의 공기청정기 제품의 풍량을 고려하여 $1,974 \mathrm{CMH}$ 으로 하며, 각 공기청정기의 적용면적을 고려하여 총 6 대를 사용하는 것으 로 가정하였다. 또한, 공기 중 오염물질을 $99.97 \%$ 제거할 수 있는 HEPA 필터가 장착된 공기청정기를 사용하는 것으로 가 정하였다.

[Table 2] Numerical Analysis Cases

\begin{tabular}{|c|c|c|c|}
\hline Case & Partitions & $\begin{array}{c}\text { UVGI } \\
\text { system }\end{array}$ & $\begin{array}{c}\text { Air } \\
\text { cleaners } \\
(1,974 \\
\mathrm{CMH})\end{array}$ \\
\hline 1 & & & \\
\hline 2 & & $\mathrm{O}$ & \\
\hline 3 & & & $\mathrm{O}$ \\
\hline 4 & \multirow{3}{*}{$\mathrm{O}$} & & \\
\hline 5 & & $\mathrm{O}$ & \\
\hline 6 & & & $\mathrm{O}$ \\
\hline
\end{tabular}

\subsection{Numerical analysis methods}

실내 상부형 UVGI의 살균효과는 미생물과 같은 물질을 이 용한 기존의 실험들로부터 간단한 실험식으로 나타낼 수 있 다. 본 연구에서 사용된 실내 상부형 UVGI의 살균효과는 식 (1)과 같다.

$$
\frac{C_{t}}{C_{0}}=e^{-k I t}
$$

$$
\begin{aligned}
& \text { 여기서, } \\
& C_{t} \text { : 시간 } \mathrm{t} \text { 에서의 미생물/오염물질의 농도 }(-) \\
& C_{0} \text { : 초기 미생물/오염물질의 농도 }(-) \\
& t: \text { 자외선 폭로 시간 }(\mathrm{sec}) \\
& k: \text { 자외선 살균계수 }\left(\mathrm{m}^{2} / \mathrm{J}\right) \\
& I: \text { 자외선 강도 }\left(\mathrm{W} / \mathrm{m}^{2}\right)
\end{aligned}
$$

식 (1)에서 살균계수 $k$ 는 자외선에 대한 각 미생물의 살균 특성으로 바이러스나 세균과 같이 $\mathrm{k}$ 가 큰 미생물들은 비교적 자외선 살균이 잘 되며, 곰팡이와 같이 $\mathrm{k}$ 가 작은 미생물들은 
자외선에 비교적 강하다. 본 연구에서는 Influenza A 바이러 스의 살균계수인 0.27 을 사용하였다.

수치해석에 적용된 공기감염균에 대한 실내 상부형 UVGI 의 살균효과는 식 (2)와 같은 스칼라 수송방정식으로 풀 수 있다.

$$
\frac{\partial C}{\partial t}+\frac{\partial U C}{\partial x_{j}}=\frac{\partial}{\partial x_{j}}\left(\frac{v_{t}}{\sigma} \frac{\partial C}{\partial x_{j}}\right)+S
$$

식 (2)에 식(1)을 미분하여 공기감염균의 생성항인 S에 대 입하면, 자외선에 의해 공기감염균의 농도 감소에 관한 식 (3) 을 구할 수 있다.

$$
\frac{\partial C}{\partial t}+\frac{\partial U C}{\partial x_{j}}=\frac{\partial}{\partial x_{j}}\left(\frac{v_{t}}{\sigma} \frac{\partial C}{\partial x_{j}}\right)-k I C
$$

본 연구에서는 대상 모델 내에 형성된 자외선 강도의 공간 분포를 입력하여 식 (3)을 통해 실내 상부형 UVGI의 공기감염 균 제거 효과를 계산하였다.

공기청정기의 경우 오염물질의 입자크기가 $0.3 \mu \mathrm{m}$ 이상 일 때, 오염물질을 $99.97 \%$ 제거 가능한 HEPA 필터를 사용한 것 으로 가정하였다. 따라서 공기청정기의 오염물질 제거 효과는 식 (4)와 같이 계산할 수 있다.

$$
C_{s u}=\beta \times C_{r e}
$$

여기서,
$C_{s u}$ : 공기청정기에서 공급되는 공기의 오염물질 농도 $C_{r e}$ : 공기청정기에서 유입되는 공기의 오염물질 농도

$\beta$ : HEPA 필터의 오염물질 제거율 (99.97\%)

본 연구에서 수치해석을 통해 얻어진 오염물질의 농도는 상대적인 값이다. 분석 시 사용한 Passive scalar는 가스상 물 질이다. 가스상 오염물질의 발생 농도를 1 로 하여 주변의 농 도는 발생 농도와의 상대적인 계산 값이다. 발생 농도가 1이 기 때문에 가장 높은 값은 1 이며, 1 보다 작고 0 에 가까울수록 오염물질의 농도가 낮은 것이다.

\section{Results of Numerical analysis}

\subsection{Infectious Pollutant Concentrations}

[Figure 2]는 각 감염확산 저감 장치 별 공기감염균의 농도 분포를 수치해석을 통해 분석한 결과이다. 그림 2에서 나타내 는 공기감염균의 농도 분포는 임시대피소 내 재실자의 생활 에 영향을 줄 수 있는 높이 $0.8 \mathrm{~m}$ 에서 공기감염균의 농도 분포 를 나타낸다. 그림 2 를 통해 각 감염확산 저감 장치 별 공기감 염균의 확산 정도를 확인할 수 있다.

자연환기이며 아무런 저감 장치가 없는 Case 1 의 경우, 급 기구 쪽의 공기감염균의 농도가 낮고 배기구 쪽과 감염환자 의 주변의 공기감염균의 농도가 높게 나타났다. 칸막이 없이 실내 상부형 UVGI를 사용한 Case 2의 경우 실내 상부형 UVGI에 의해 공기감염균의 확산이 크게 이루어지지 않은 것 을 확인할 수 있었다. 마찬가지로 칸막이 없이 공기청정기를 사용한 Case 3의 경우, 공기감염균이 Case 1에 비해서는 확 산이 적으나, 실내 상부형 UVGI에 비해서는 공기감염균이 임 시대피소 내에서 확산된 것으로 나타났다. 칸막이 만을 사용

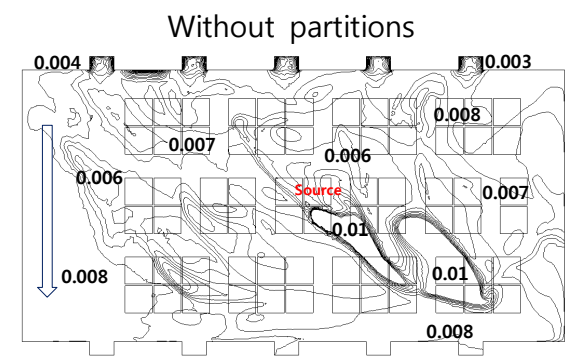

(1) Case 1

With partitions

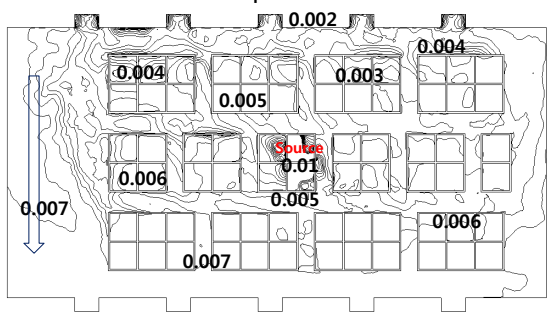

(4) Case 4

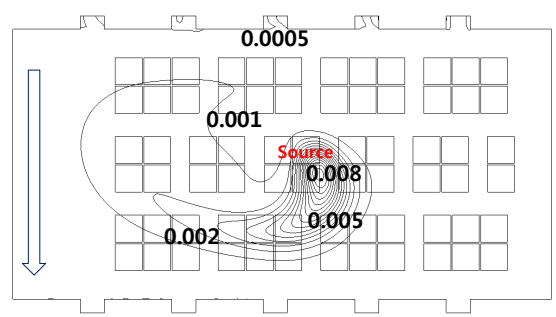

(2) Case 2 (UVGI)

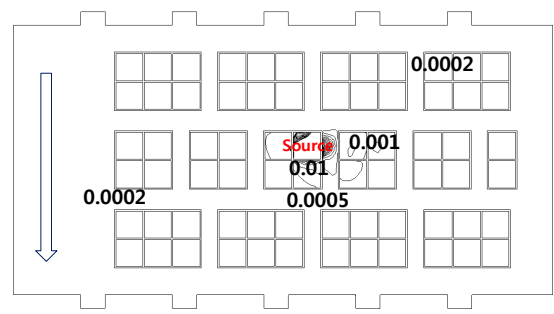

(5) Case 5 (UVGI)

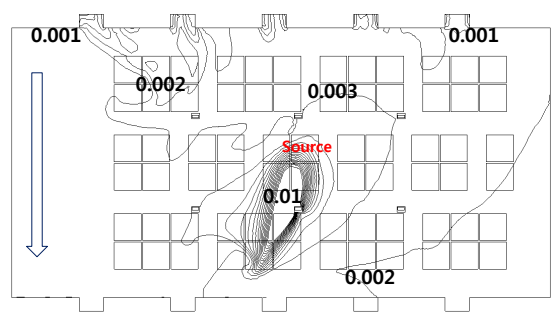

(3) Case 3 (Air cleaners)

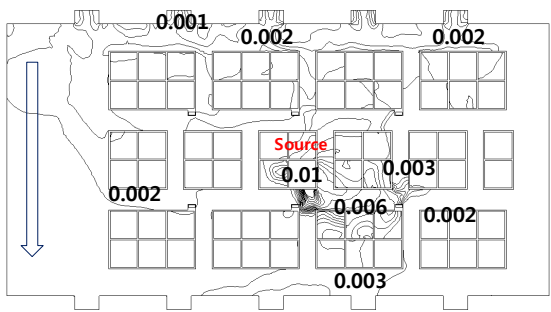

(6) Case 6 (Air cleaners)

[Figure 2] Infectious Pollutant Concentration Distribution 
한 Case 4의 경우 자연환기 만을 한 Case 1에 비해 공기감염 균의 확산이 낮은 것을 확인하였다. 그 외 칸막이와 실내 상부 형 UVGI를 같이 사용한 Case 5 와 칸막이와 공기청정기를 같 이 사용한 Case 6의 경우, 칸막이를 사용하지 않은 Case에 비 해 공기감염균이 임시대피소 내에서 확산되지 않은 것을 확 인할 수 있었다.

임시대피소 내 공기감염균의 확산을 확인하기 위해 수치해 석을 진행한 결과, 실내 상부형 UVGI나 공기청정기와 같은 장 치가 감염확산 저감에 효과가 있는 것으로 나타났다. 또한 특 별한 장치 외에 칸막이를 설치하는 것만으로도 공기감염균의 확산을 저감할 수 있는 것으로 나타났다.

\subsection{Comparison of Mean Infectious Pollutant Concentrations}

[Figure 2]와 같이 바닥으로부터 높이 $0.8 \mathrm{~m}$ 의 농도 분포만 을 가지고 각 피난 구역별 공기감염균의 농도 및 저감 장치 별 공기감염균의 감소량을 비교하는 데에는 한계가 있다. 따 라서 각 피난 구역별 공기감염균의 농도 및 저감 장치 별 공 기감염균의 감소량을 비교하기 위해 임시대피소 내 공기감염 균의 부피 별 농도를 계산하여 비교 분석하였다.

각 장치 별 공기감염균의 확산을 저감하는 성능을 비교하 기 위해 피난 구역별, 공기감염균의 평균 농도를 자연환기만 을 한 Control case, Case 1의 공기감염균 평균 농도와 비교하 였다. 각 피난 구역별로 재실자가 생활하는데 영향을 미치는 높이인 바닥으로부터 $0.8 \mathrm{~m}$ 까지 공기감염균의 부피평균 농도 를 구하여 비교하였다 (Figure 3).

칸막이 없이 실내 상부형 UVGI를 설치한 경우 (Case 2), [Figure 3]의 (1)과 같이 공기감염균의 농도가 Case 1에 비해 최대 $90 \%$ 이상 감소하였다. 또한 감염환자가 있는 주변 피난 구역에서 공기감염균의 평균 농도도 $40 \%$ 정도 감소한 것을 확인하였다. 임시대피소 내에 칸막이 없이 공기청정기를 사용 한 경우 (Case 3), Figure 3의 (2)와 같이 급기구 주변의 피난 구역에서 공기감염균의 농도가 감소한 것을 확인하였다. 그러 나 감염환자가 있는 주변 피난 구역에서 공기감염균의 농도 가 2 배 이상 증가한 것을 확인하였다. 이는 공기청정기로 인 해 기류변화가 발생하고, 공기청정기에서 공기감염균이 제거 되어 다시 실내로 유입되는 배기구의 높이가 $0.8 \mathrm{~m}$ 보다 높아 이와 같은 결과가 나타난 것으로 판단된다.

[Figure 3]의 (3)은 특별한 장치 없이 칸막이만 사용하였을 때(Case 4)의 농도 비교를 나타낸다. Figure 3의 (3)에 의하면, 칸막이를 사용함으로 인해 공기감염균의 농도가 감소하는 것 을 확인하였다. 그러나 공기감염균의 주변 피난 구역의 경우, 칸막이로 인해 공기감염균이 기류의 영향을 받지 못하여 공 기감염균의 농도가 Case 1에 비해 증가하였다. 칸막이와 실내 상부형 UVGI를 같이 사용한 경우 (Case 5), 거의 모든 피난 구
역에서 공기감염균의 농도가 Case 1에 비해 크게 감소하였다 (Figure 3의 (4)). 그러나 칸막이의 특성상, 감염환자가 있는 피난 구역의 농도는 Case 1에 비해 높게 나타났다. 칸막이와 공기청정기를 같이 사용한 경우 (Case 6), Case 1에 비해 공기 감염균의 농도가 감소하였다 (Figure 3의 (5)). 그러나 칸막이 를 사용한 다른 Case와 마찬가지로 감염환자가 있는 피난 구 역 주변의 농도가 Case 1에 비해 높게 나타났다.

각 장치의 공기감염균의 확산 저감 및 제거 효과를 확인하 기 위해 피난 구역 내 감염 저감 장치 별 Control case 대비 공기감염균의 농도 감소 비의 평균을 확인하였다 (Table 3). 그 결과, 실내 상부형 UVGI나 공기청정기 또는 칸막이를 사용 하였을 경우 control case에 비해 공기감염균이 감소한 것을 확인하였다. 이를 통해 실내 상부형 UVGI와 공기청정기, 칸막 이를 사용하여 임시대피소 내 공기감염균의 확산을 저감하는 것이 가능한 것을 확인하였다. 그러나 각 감염 저감 장치 별로 공기감염균의 농도 분포는 다르게 나타났다. 실내 상부형 UVGI의 경우 칸막이 유무에 상관없이 전체 피난 구역에서 공 기감염균의 농도가 Case 1에 비해 크게 감소하였다. 그러나 공기청정기의 경우, 일부 피난 구역에서 공기감염균의 농도가 자연환기만을 한 Case 1에 비해 높게 나타났다. 또한 칸막이 를 사용할 경우, 감염환자가 있는 피난 구역 내의 공기감염균 의 농도가 가장 높게 나타났다. 이를 통해, 공기청정기의 경우 공기감염균의 피난 구역 전체 평균 농도는 감소하나 일부 구 역에서는 기류의 영향으로 공기감염균의 농도가 증가하는 것 을 확인하였다. 마찬가지로 칸막이를 사용한 경우, 공기감염 균의 확산을 저감할 수 있으나 칸막이로 인해 감염원 근처의 농도가 높게 나타났다.

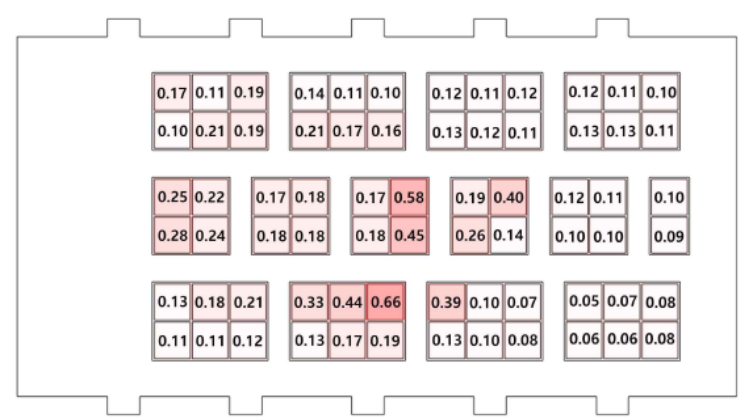

(1) Case $2(U)$

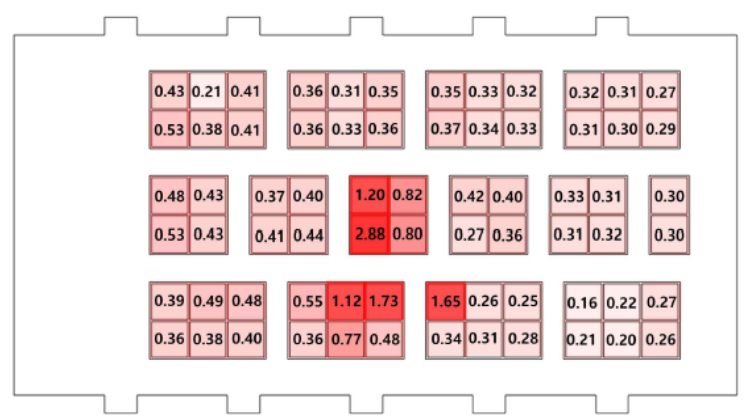

(2) Case 3 (A) 


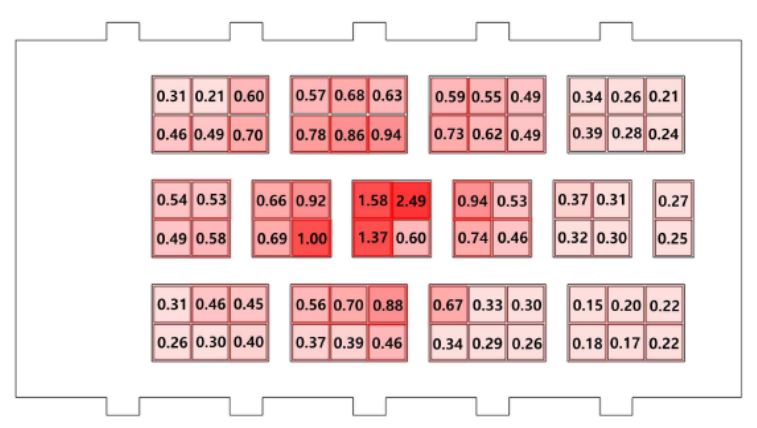

(3) Case $4(P)$

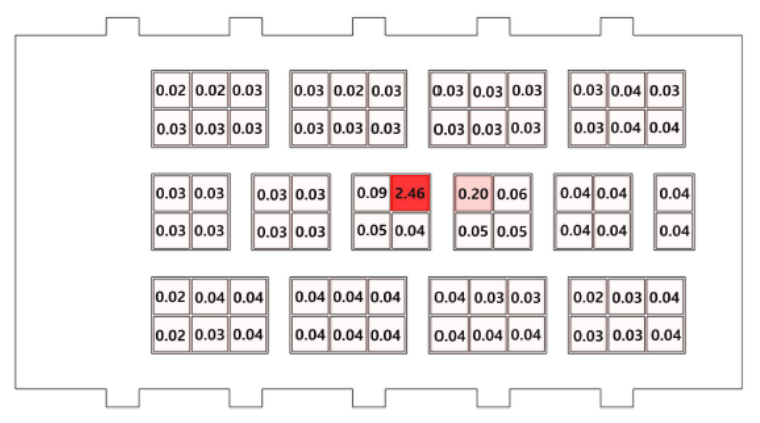

(4) Case $5(P, U)$

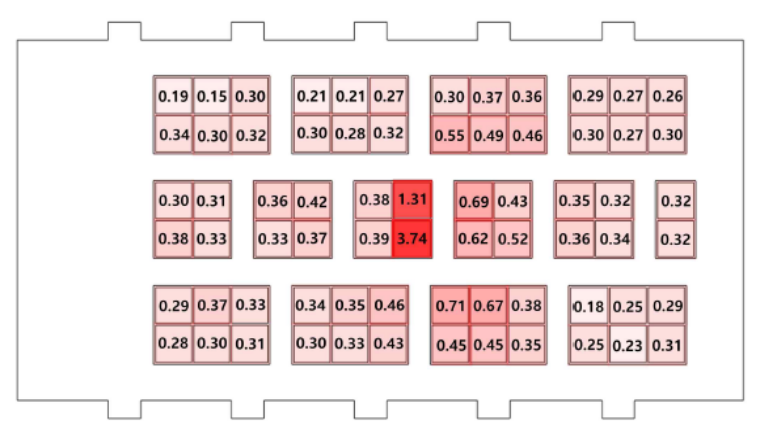

(5) Case $6(P, A)$

* (U: UVGI, A: Air cleaners, P: Partitions)

[Figure 3] Ratio of Mean Infectious Pollutant Concentration to Case 1

[Table 3] Mean Infectious Pollutant Concentration Ratio of 70 Units

\begin{tabular}{c|c}
\hline Case & $\begin{array}{c}\text { Mean infectious pollutant } \\
\text { concentration ratio }\end{array}$ \\
\hline $2(\mathrm{U})$ & 0.1718 \\
\hline $3(\mathrm{~A})$ & 0.4676 \\
\hline $4(\mathrm{P})$ & 0.5531 \\
\hline $5(\mathrm{P}, \mathrm{U})$ & 0.0710 \\
\hline $6(\mathrm{P}, \mathrm{A})$ & 0.3964 \\
\hline
\end{tabular}

*(U: UVGI, A: Air cleaners, P: Partitions)

\subsection{Discussion}

1) Discussion of Airborne Infection Source's Location

실제 임시대피소 내에서는 공기감염 환자의 위치를 확인하 여 공기감염균의 확산을 저감하는 장치를 설치하는 데에 한 계가 있다. 따라서 공기감염균의 확산 및 확산을 저감하기 위 한 장치를 설치할 경우, 공기감염균의 발생위치에 따른 장치 의 감염확산 저감 성능을 파악할 필요가 있다. 이를 확인하기 위해 본 연구에서는 공기감염균의 발생위치를 실의 중앙이 아닌 급기 측과 배기 측으로 변경하여 추가 분석을 진행하였 다. 공기감염균의 발생위치는 [Figure 4]와 같이 가정하여 추 가 분석을 진행하였다. [Figure 4]의 화살표는 기류의 방향을 나타낸다.

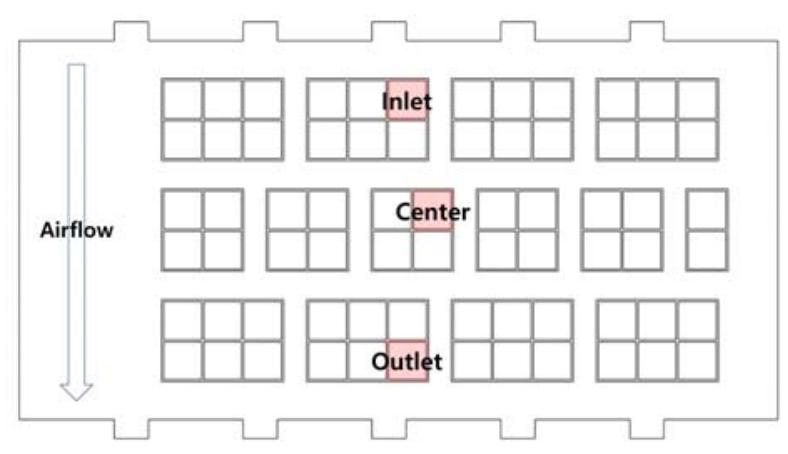

[Figure 4] Location of Airborne Infection Source

[Table 4]는 공기감염균의 발생위치를 제외한 피난 구역의 바닥으로부터 높이 $0.8 \mathrm{~m}$ 까지의 공기감염균 평균 농도를 나타 낸다. 공기감염균의 발생 위치 따른 영향을 분석하기 위해, 공 기감염균의 발생위치에서 공기감염균의 농도는 제외하고 그 외 피난 구역의 공기감염균 농도를 분석하여 비교를 진행하 였다.

[Table 4] Mean Pollutant Concentration of Each Airborne Infection Source's Location

\begin{tabular}{c|c|c|c|c|c|c}
\hline \multirow{2}{*}{$\begin{array}{c}\text { Source's } \\
\text { location }\end{array}$} & \multicolumn{6}{|c}{ Mean pollutant concentration } \\
\cline { 2 - 7 } & Case 1 & Case 2 & Case 3 & Case 4 & Case 5 & Case 6 \\
\cline { 2 - 7 } & $\mathrm{C}$ & $\mathrm{U}$ & $\mathrm{A}$ & $\mathrm{P}$ & P, U & P, A \\
\hline Center & 0.0069 & 0.0012 & 0.0031 & 0.0033 & 0.0002 & 0.0035 \\
\hline Inlet & 0.0021 & 0.0006 & 0.0029 & 0.0047 & 0.0010 & 0.0020 \\
\hline Outlet & 0.0015 & 0.0005 & 0.0024 & 0.0023 & 0.0006 & 0.0019 \\
\hline
\end{tabular}

*(C: Control case, U: UVGI, A: Air cleaners, P: Partitions)

공기감염균이 배기 측에서 발생하는 경우, 모든 케이스에 서 임시대피소 내 피난 구역 공기감염균의 평균 농도가 가장 
낮게 나타났다. 이는 공기감염균이 발생하여도 빠른 시간 내 에 임시대피소 밖으로 배기되어 실내의 농도가 가장 낮다. 공 기감염균이 급기 측에서 발생하는 경우, 공기감염균이 기류를 타고 실내로 확산 되어 공기감염균의 농도가 비교적 높게 나 타났다. 특히 칸막이만을 사용한 경우 (Case 4) 공기감염균이 급기 측에서 발생할 때 공기감염균의 농도가 가장 높게 나타 났다. 이는 급기 측에서 발생한 공기감염균이 기류를 타고 확 산 되다 칸막이로 인해 빠져나가지 못하고 정체되어 농도가 높게 나타난 것으로 예상된다. 또한 배기 측에서 공기감염균 이 발생하여도 칸막이만을 설치한 경우 (Case 4)의 공기감염 균의 평균 농도가 자연환기만 할 때 (Case 1)의 공기감염균 평균 농도 보다 높게 나타났다. 칸막이로 인해 기류가 정체 되 어 피난 구역 내에서 발생한 공기감염균이 임시대피소 밖으 로 배기 되지 못해 이와 같은 결과가 나타난 것으로 보인다.

공기감염균의 발생 위치에 상관없이, 실내 상부형 UVGI를 사용한 경우 피난 구역 내 공기감염균의 농도가 가장 낮게 나 타났다. 이를 통해 실내 상부형 UVGI가 실제 감염환자, 공기 감염균의 발생위치를 확인할 수 없는 임시대피소 내에서 사 용될 때 감염 확산 저감 성능이 뛰어날 것으로 보인다. 반면에 공기청정기의 경우, 기류에 영향을 주기 때문에 공기감염균의 발생 위치가 변하여도 피난 구역 별 평균 농도 값은 크게 변 하지 않는 것을 확인하였다. 특히 칸막이 없이 공기청정기만 을 사용한 경우, 공기감염균의 위치와 상관 없이 피난 구역 내 공기감염균의 농도가 높게 나타났다. 공기청정기로 인해 실내 기류가 변하여 공기감염균이 각 피난 구역으로 확산되어 이 와 같은 공기감염균의 농도 분포가 나타난 것으로 보인다.

\section{2) Discussion of using Air Cleaners}

공기청정기의 경우 수치해석 결과에서 확인할 수 있듯이 기류에 영향을 미쳐 공기감염균의 농도가 일부 피난 구역에 서 높아지는 것을 확인하였다. 이를 방지하기 위해 공기청정 기의 설치 위치나 풍량을 설정하는 것이 중요하다. 공기청정 기의 풍량이 공기감염균의 확산 저감에 미치는 영향을 확인 하기 위해, 본 연구에서 추가적으로 공기청정기의 풍량을 $987 \mathrm{CMH}$ 로 감소하여 수치해석을 진행하였다. 기류의 영향을 확인하기 위해 칸막이가 없이 공기청정기만 사용하는 것으로 가정하여 분석을 진행하였다.

[Figure 5] 의 (1)은 재실자에게 영향을 미칠 수 있는 높이 인 $0.8 \mathrm{~m}$ 에서의 공기감염균의 농도 분포를 나타낸다. 풍량 $1,974 \mathrm{CMH}$ 의 공기청정기를 사용한 케이스와 비교하기 위해 자연환기만을 한 Case 1대비 공기감염균의 농도 비를 각 피 난 구역 별로 나타내었다 (Figure 5 의 (2)). 풍량 $987 \mathrm{CMH}$ 의 공기청정기를 사용한 경우, 전체 70 개의 피난 구역 내 공기감 염균의 평균 농도가 풍량 $1,974 \mathrm{CMH}$ 의 공기청정기를 사용한 경우에 비해 약 1.65 배 높은 것을 확인하였다. 이를 통해 공기
청정기의 풍량이 클수록, 임시대피소 내 피난 구역의 공기감 염균 평균 농도가 낮아지는 것으로 고찰된다.

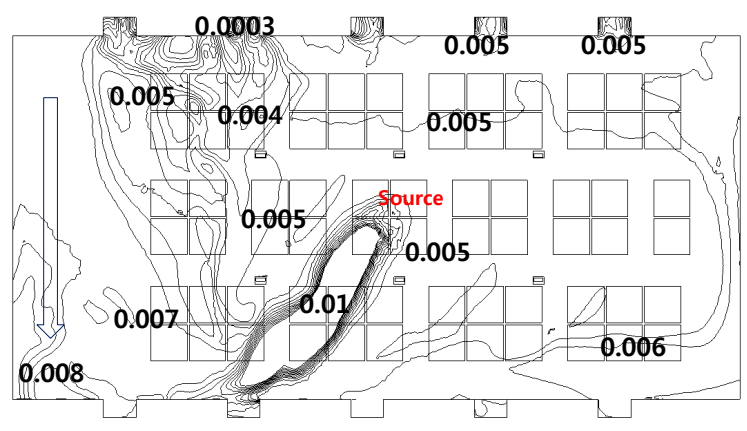

(1) Infectious pollutant concentration distribution of Air cleaners (987 CMH)

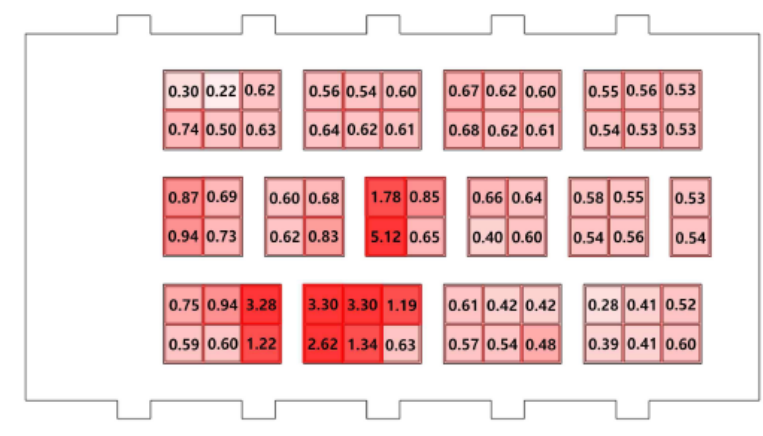

(2) Comparison of mean infectious pollutant concentration to Case 1

[Figure 5] Infectious Pollutant Concentration of Air Cleaners (987 CMH)

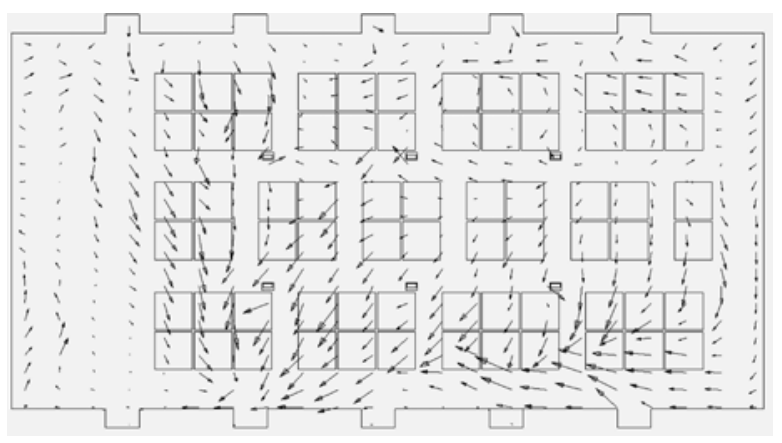

(1) Air cleaners (987 CMH)

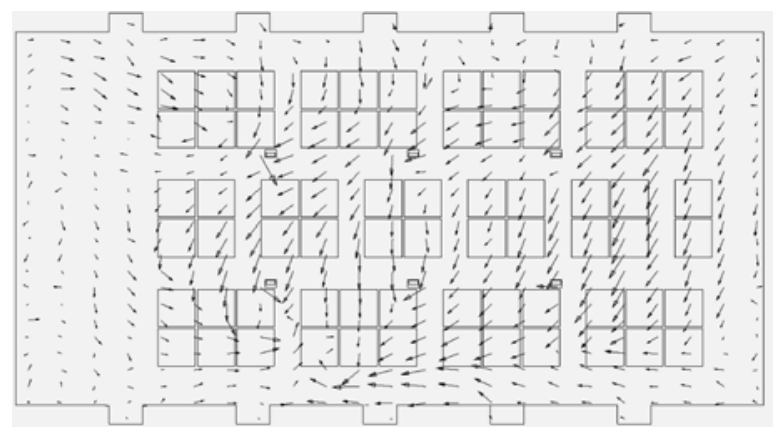

(2) Air cleaners $(1,974 \mathrm{CMH})$

[Figure 6] Air Flow of Air Cleaners (987 CMH, 1,974 $\mathrm{CMH}$ ) 
공기청정기의 풍량 변화가 감염확산 저감 성능에 미치는 영향을 확인하기 위해 공기청정기를 사용한 Case의 기류 분 포를 확인하였다. 그림 6 은 높이 $0.8 \mathrm{~m}$ 에서의 기류 분포를 화살표의 길이를 통해 나타내었다. [Figure 6]의 (1)과 (2)를 통해, 공기청정기의 풍량이 높을수록 임시대피소 내에 비교 적 빠른 기류가 형성되는 것을 확인하였다. 이 같이 임시대 피소 내에 빠른 기류가 형성 되어 실내 공기의 순환이 가능 해짐으로 인해, 실내의 공기감염균의 농도가 낮아진 것으로 고찰된다.

\section{Conclusion}

본 연구에서는 임시대피소 내에서의 공기감염병의 확산을 예방하기 위하여 공기감염균의 농도를 저감시킬 수 있는 방 법을 검토하고 그 효과를 확인하였다. 수치해석을 통해 비교 한 결과는 다음과 같다.

1) 실내 상부형 UVGI나 공기청정기와 같은 저감 장치를 사 용한 경우, 임시대피소 내에 공기감염균의 농도를 감소시키는 데에 효과적이다. 칸막이의 경우, 칸막이를 설치함으로 인해 임시대피소 내에 공기감염균이 확산되는 것을 저감할 수는 있다. 그러나 감염환자가 있는 피난 구역이나 그에 인접한 피 난 구역은 칸막이의 특성상 공기감염균이 확산되지 않아 농 도가 높아질 위험이 있다.

2) 공기감염균의 발생위치를 달리하여 수치해석을 진행한 결과, 실내 상부형 UVGI가 공기감염균의 발생위치에 상관없 이 감염 확산 저감 성능이 높게 나타났다. 공기청정기 풍량이 감염확산 저감 성능에 미치는 영향을 확인하기 위해 추가적 인 수치해석을 진행한 결과, 공기청정기 풍량이 증가함으로 인해 실내에 비교적 빠른 기류가 형성되어 환기횟수가 증가 하여 임시대피소 내의 공기감염균의 농도가 낮아지는 것을 확인하였다.

3) 본 연구를 통해, 공기감염균의 확산을 저감하기 위한 최 적의 장치는 실내 상부형 UVGI를 사용하는 것임을 확인하였 다. 그러나 재실자의 사생활 보호 등을 고려하여 칸막이를 함 께 사용하는 방안을 권장함이 적절하다.

4) 마지막으로 본 연구에서는 공기감염균이 비교적 작은 입자로 구성되어 확산이 잘되는 것을 가정하여 공기감염균을 가스상 물질로 가정하였다. 그러나 실제 공기감염균은 입자상 물질로 입자상 물질로 가정하여 수치해석을 진행할 경우, 본 연구의 결과와 차이를 보일 수 있다. 또한 임시대피소의 특성 상 다양한 규모의 건물이 사용될 수 있으나 본 연구에서는 대 규모 실내 체육관을 대상으로 분석하여 소규모 임시대피소 건물에서의 공기감염균 확산 저감 대책을 확인하기에는 한계 가 있다. 이러한 한계점을 보완하기 위해 추후 다양한 임시대 피소 모델 및 실제 공기감염균을 모사한 입자상 물질로 분석
을 진행하여 각 장치 별 공기감염균 확산 저감 성능을 확인해 야 한다.

Acknowledgements: This work was supported by the faculty research fund of Sejong University in 2012

\section{References}

APIC, 2008b, Infection prevention and control for shelters during disasters, 2007/2008 APIC Emergency Preparedness Committee

CITC, 2013, "Shelters and TB: What Staff Need to Know, 2nd edition", Curry International Tuberculosis Center

Coker, I.; et al., 2001, Guidelines for the utilization of Ultraviolet germicidal irradiation (UVGI) technology in controlling transmission of tuberculosis in health care facilities in South Africa, Medical Research Council, Pretoria, pp.1-40

Huang, Jeng-Ming, et al., 2011c, The Effect of Ventilation Types on Pollutant Removal in a Large space plant with multiple pollutant source, Indoor and Built Environment, 20, pp.488-500

Kanamori, Hajime; et al., 2013a, Tuberculosis exposure among evacuees at a shelter after earthquake Japan 2011, Emerging Infection Diseases 19, pp.799-801

Nardell, Edward; et al., 2013, Upper-Room Ultraviolet Germicidal Irradiation (UVGI) for Air Disinfection: A Symposium in Print, Photochemistry and photobiology, 89, pp.764-769

Nardell, Edward; et al., 2008, Safety of Upper-Room Ultraviolet Germicidal Air Disinfection for Room Occupants: Results from the Tuberculosis Ultraviolet Shelter Study, Public health reports 123, pp.52-60

Noakes, C.J.; et al., 2006, Use of CFD modelling to optimize the design of Upper-room UVGI disinfection systems for ventilated Rooms, Indoor and Built Environment, 15, pp.347-356

OSHA, 2009, Pandemic Influenza Preparedness and Response Guidance for Healthcare Workers and Healthcare Employers, Occupational Safety and Health Administration U.S. Department of Labor, 3328, pp.3-95

Public Health Seattle \& King County, 2010, "Tuberculosis Prevention and Control Guidelines For Homeless Service Agencies in Seattle-King Country, Washington, 4th edition", Public Health Seattle \& King County, Prevention Division-Tuberculosis Control Program

Sung, Minki; Kato, Shinsuke, 2011a, Estimating the germicidal effect of upper-room UVGI system on exhaled air of patients based on ventilation efficiency, Building and Environment, 46, pp.2326-2332

Sung, Minki; et al., 2011b, Disinfection performance of ultraviolet germicidal irradiation systems for the microbial contamination on an evaporative humidifier, HVAC\&R Research, 17, pp.22-30

USA-Centers for Disease Control and Prevention, 2008a, Environmental Health Shelter Assessment form Instruction sheet, CDC shelter assessment tool

Wrezel, Olga, 2009, Respiratory infections in the homeless, UWO Medical Journal, 78, pp.62-65

박정연; 성민기, 2014, 임시대피소를 대상으로 한 공기청정기와 자외선 
살균장치의 공기감염 제어성능 수치해석, 건축학회추계학술발표대 회 논문집, 34, pp.271-272

정선영, 2011d, 격리방법 길라잡이, Hanyang Medical Reviews, 31, pp.190-199

접수 : 2014년 12월 31일 1차 심사 완료 : 2015년 1월 27일 게재확정일자 : 2015년 1월 27일 3 인 익명 심사 필 